\title{
Frequency in the supply of Lactobacillus influence its probiotic effect for yellow tail lambari
}

\section{Adolfo Jatobá ${ }^{*} \odot{\text { Klayton Natan } \text { Moraes }^{1} \text { Emanuel Fernandes Rodrigues }}^{1}$ Leandro Marcolino Vieira ${ }^{1}$ Marina Oliveira Pereira ${ }^{1}$}

${ }^{1}$ Laboratório de Aquicultura, Instituto Federal Catarinense (IFC), Araquari, 89245-000, Santa Catarina, SC, Brasil. E-mail: jatobaadolfo@gmail.com. ${ }^{*}$ Corresponding author.

ABSTRACT: The aim of this research was to evaluate the changes in intestinal tract microbiota, hematological parameters and zootechnical indexes of yellowtail lambaris (Astyanax bimaculatus) fed with different probiotic supply frequencies (Lactobacillus spp.). Lambaris (1,200) were distributed in twelve boxes, divided in three treatments, $100 \%$ supply; $25 \%$ and $0 \%$ (control) of feeds supplemented with probiotic. After 87 days, fish fed with supplemented diet, regardless of frequency (100\% and 25\%), showed an increase in the total lactic acid bacteria count of $7.99 \pm 0.15 \log C F U m L^{-1}$ and $7.04 \pm 1,29 \log U F C \mathrm{~mL}^{-1}$ respectively, in the intestinal tract and decrease of Pseudomonas spp. in both $100 \%$ and $25 \%\left(4.09 \pm 0.84 \log U F C \mathrm{~mL}^{-1}\right.$ and $4.00 \pm 1.12 \log U F C \mathrm{~mL}^{-1}$, respectively) in relation to the control treatment (6.74 $\left.\pm 1.04 \log U F C \mathrm{~mL} L^{-1}\right)$. Fish fed with $100 \%$ of diets supplemented with probiotics had a higher leukocyte count $\left(47.7 \pm 6.7 x 103 \mu L^{-1}\right)$, lymphocytes $\left(36.0 \pm 2.6 x 103 \mu L^{1}\right)$, monocytes $\left(12.0 \pm 4.2 \times 103 \mu l^{-1}\right)$, as well as higher mean final weight $(10.60 \pm 0.89 \mathrm{~g})$ and weekly growth rate $\left(0.80 \pm 0.08 \mathrm{~g}\right.$. week $\left.{ }^{-1}\right)$ than the other treatments (25\% of probiotic offered and control). Probiotic (Lactobacillus spp.) offered in $25 \%$ offeeds (or more) alters the yellowtail lambari microbiota (A. bimaculatus); however, must be offer in 100\% of feeds to improve the hematology profile and productive performance. Key words: food handling, lactic acid bacteria, Astyanax, hematology, microbiota.

\section{Frequência no fornecimento de Lactobacillus influencia seu efeito probiótico para o lambari-do-rabo-amarelo}

RESUMO: $O$ objetivo deste trabalho foi avaliar as alterações na microbiota do trato intestinal, parâmetros hematológicos e indices zootécnicos de lambaris-do-rabo-amarelo (Astyanax bimaculatus) alimentados com diferentes frequências de oferta do probiótico (Lactobacillus spp.). Os lambaris (1.200) foram distribuidos em doze caixas, divididos em três tratamentos, oferta de $100 \%$, 25\% e 0\% (controle) de alimentações suplementadas com probiótico. Após 87 dias, os peixes alimentados com dieta suplementada, independente da frequência

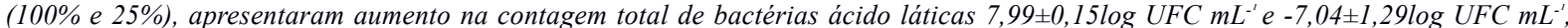
respectivamente, no trato intestinal e redução de Pseudomonas spp. tanto em $100 \%$ quanto em $25 \%\left(4,09 \pm 0,84\right.$ log UFC mL $L^{-1}$ e 4,00 $\pm 1,12$ $\log U F C \mathrm{~mL}^{-1}$, respectivamente) em relação ao tratamento controle $\left(6,74 \pm 1,04 \log U F C \mathrm{~mL}^{-1}\right)$. Os peixes alimentados com $100 \%$ das dietas suplementadas com probiótico apresentaram maior contagem de leucócitos $\left(47,7 \pm 6,7 \times 10^{3} \mu L^{-1}\right)$, linfócitos $\left(36,0 \pm 2,6 x 10^{3} \mu L^{-1}\right)$, monócitos $\left(12,0 \pm 4,2 \times 10^{3} \mu \mathrm{L}^{-1}\right)$, assim como maior peso médio final $(10,60 \pm 0,89 \mathrm{~g})$ e taxa de crescimento semanal $\left(0,80 \pm 0,08 \mathrm{~g}\right.$. semana $\left.^{-1}\right)$ que os demais tratamentos (25\% de oferta de probiótico e controle). O probiótico (Lactobacillus spp.) oferecido em 25\% de alimentos (ou mais) altera a microbiota de lambari de rabo amarelo (A. bimaculatus), no entanto, deve ser oferecido em $100 \%$ de alimentos para melhorar o perfil hematologia e desempenho produtivo.

Palavras-chave: manejo alimentar, bactérias ácido láticas, Astyanax, hematologia, microbiota.

\section{INTRODUCTION}

In conventional fish culture animals are exposed directly to several microorganisms present in the environment, both beneficial and pathogenic. Probiotics reduce the need for investments with antimicrobials and parasiticides; consequently, reducing the use of chemotherapeutics and their environmental impacts caused by fish culture (HAI, 2015), its use offers a very promising alternative to the use of antibiotics in production systems of aquaculture (VASEEHARAN \& RAMASAMY, 2003).
A probiotic is defined as a living microbial adjuvant that has a beneficial effect on the host by modifying the microbial community associated with the host or environment (VERSCHUERE et al., 2000) as vibrio reduction on water (VASEEHARAN et al, 2004). Among probiotic microorganisms, lactic acid bacteria (LAB) have shown great efficacy to fish with results in the improvement of zootechnical indexes, weight gain, specific growth rate, feed conversion ratio (JATOBÁ et al., 2011; STANDEN et al., 2016), as a histological changes of the gastrointestinal tract, inducing an increase in villus height and width as well 
as epithelial cell thickness (MELLO et al., 2013), besides acting as promoters of the immune system (JATOBÁ et al., 2008; TELLI et al., 2014).

Several factors may alter the efficiency of probiotics, such as method of administration, mode of incorporation, inoculum/feed ratio, quantity supplied by fish $(\% / \mathrm{kg})$, as well as frequency of supply (HAI, 2015). However, few studies have evaluated different methods of application, mainly for Brazilian native species. Among them, the yellowtail lambari (Astyanax bimaculatus) has been highlighted due its desirable characteristics to fish culture such as: omnivorous food habit, short life cycle, and can be used as a main, secondary or forage species, as well as can be reared in the different culture systems (PORTO-FORESTI et al., 2005).

The objective of this research was to evaluate the intestinal tract microbiota, hematological parameters and growth performance of yellow tail lambaris (A. bimaculatus), fed with different frequencies in the supply of probiotic (Lactobacillus spp.).

\section{MATERIALS AND METHODS}

The study was carried out in the Laboratório de Aquicultura (LAQ), Instituto Federal Catarinense (IFC), campus Araquari, (Protocol number 0219/2017 approved by animal ethics committee).

The Lactobacillus strain CPQBA 116815 DRM-01 with proven probiotic effect in vitro and in vivo (JATOBÁ et al., 2017) and 1200 yellow tail lambari (A. bimaculatus), average weight $1.0 \pm 0.2 \mathrm{~g}$, were used.

Fish were distributed in 12 experimental units under outdoor conditions, 100 fish per box, with a capacity of $800 \mathrm{~L}$, equipped with biological filters and recirculation system. Boxes were divided into three treatments (Table 1), with four replicates. According to the protocols established by JATOBÁ et al. (2011), 10\% of inoculum was included in the probiotic diets with Lactobacillus strain and
MRS medium (Lactobacillus MRS Broth, HiMedia Laboratories Pvt., India), and only sterile MRS medium (Lactobacillus MRS Broth, HiMedia Laboratories Pvt., India) in the control diet. Probiotic diets were only used when concentrations $\geq 1.0 \times 10^{7}$ CFU.g ${ }^{-1}$ were observed.

Fish were fed three times a day (09:00, 13:00 and 16:00) with a commercial $\operatorname{diet}\left(\mathrm{GUABI}^{\circledR}\right.$, $1.7 \mathrm{~mm}, 36 \%$ crude protein and $6.5 \%$ ethereal extract, manufacturer's warranty levels), with $4 \%$ of their biomass, and biometrics were performed weekly for food management. Dissolved oxygen and temperature were measured twice a day, while $\mathrm{pH}$ and ammonia were measured weekly.

After 87 days of rearing and a $24 \mathrm{~h}$ period of starvation, eight animals per experimental unit were anesthetized with Eugenol $\left(50 \mathrm{mg} \mathrm{L}^{-1}\right)$ and sacrificed by cerebral concussion. Three were used for the microbiological assays of digestive tract, and the others were used for hematological analysis.

For microbiological assays of the digestive tract, the guts of three fish from each tank were removed and pooled to microbiological and histological tests. Pooled fish guts were homogenized and serially diluted $1: 10$ in $0.65 \%$ of $\mathrm{NaCl}$ sterile saline. Samples from each dilution were cultured in TSA (Triptone Soy Agar, HiMedia Laboratories Pvt. Ltd., India), TCBS (Agar Thiosulfate Citrate Bile Sucrose, HiMedia Laboratories Pvt. Ltd., India), Cetrimide (Cetrimide Agar, HiMedia Laboratories Pvt. Ltd., India), and then incubated for $24 \mathrm{~h}$ at $30^{\circ} \mathrm{C}$, as well as MRS (Lactobacillus MRS Agar, HiMedia Laboratories Pvt. Ltd., India), followed by incubation for $48 \mathrm{~h}$ at $35^{\circ} \mathrm{C}$, for viable cultivable heterotrophic bacterial counts, including Vibrio spp., Pseudomonas spp. and lactic acid bacteria (LAB), respectively.

For hematological analysis, approximately $1.0 \mathrm{~mL}$ of blood was drawn from the caudal vein of each fish for the preparation of blood smears, in duplicate, and the following hematological analyses: determination of hematocrit by standard microhematocrit method; glucose with digital readers

Table 1 - Experimental treatments, probiotic supply frequency during yellowtail lambari (A. bimaculatus) culture.

\begin{tabular}{|c|c|c|c|c|c|}
\hline \multirow[t]{2}{*}{ Treatment } & \multirow{2}{*}{$\begin{array}{c}\text { Day } \\
\text { Period }\end{array}$} & \multicolumn{2}{|c|}{ 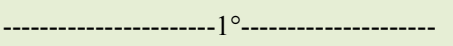 } & \multicolumn{2}{|c|}{ 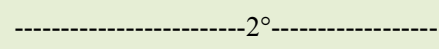 } \\
\hline & & Morning & Afternoon & Morning & Afternoon \\
\hline & $100 \%$ & $X$ & $X$ & $X$ & $X$ \\
\hline \multirow[t]{2}{*}{ Probiotic supply frequency } & $25 \%$ & $X$ & - & - & - \\
\hline & $0 \%$ & - & - & - & - \\
\hline
\end{tabular}


(G-TECH free ${ }^{\circledR}$, Accumed-Glicomed, Brazil); total hemocyte count by Neubauer hemocytometer. Blood smear slides were stained with Giemsa and May Grünwald stain (ROSENFELD, 1947) for total and differential leukocyte count.

Survival (SR), final weight (FW), weekly weight gain (WWG), consumption, specific growth rate (SGR), apparent feed efficiency (SGR) and yield were all determined at the end of the experiment, according to the formulas below:

$\mathrm{SR}(\%)=\left[\mathrm{N}^{\circ}\right.$ of live individuals $/ \mathrm{N}^{\circ}$. of individuals introduces $]^{*} 100$.

WWG $\left(\right.$ g.week $\left.{ }^{-1}\right)=($ Final weight-Initial weight $) / \mathrm{n}^{\circ}$ of week.

SGR $\left(\%\right.$ day $\left.^{-1}\right)=[(\log ($ Final weight $)-\log ($ Initial weight $)) / \mathrm{n}^{\circ}$ of days] $]^{*} 100$.

$\mathrm{AFE}=($ Final weight - Initial weight $) /$ consumption .

Yield $\left(\mathrm{kgm}^{-3}\right)=($ Final Biomass-Initial Biomass $) /$ pond area.

All data were first subjected to Bartlett's analysis, to verify the homogeneity of variance, one-way ANOVA and significant differences among treatments were analyzed using the Student-Newman-Keuls (SNK) test of means separation. Microbiological data were $\log (\mathrm{x}+1)$ transformed. All tests were conducted at a 5\% level of significance.

\section{RESULTS AND DISCUSSION}

Diets supplemented, regardless of the probiotic supply frequency, had a higher LAB and lower Pseudomonas spp. in the intestinal tract in relation to the control (Table 2), while in counting of total heterotrophic bacteria and Vibrionaceas there was no difference between treatments.

Results corroborate with JATOBÁ \& MOURIÑO (2015) who observed the increase of LAB in the intestinal tract of Nile tilapia fed with probiotic diet (L. plantarum) during 35 days. However, they were divergent with STANDEN et al. (2016) who recorded a higher amount of Bacillus in the intestinal tract of Nile tilapia (O. nilotcus) only in the treatment that received the highest concentration ( $3 \mathrm{~g}$ of probiotic per $\mathrm{kg}$ ) in the diet, already for total heterotrophic bacteria both works did not observe changes in the microbiota.

Some researches (JATOBÁ et al., 2008; 2011; JATOBÁ \& MOURIÑO, 2015) have observed a reduction in the counts of total heterotrophic bacteria in the intestinal tract of fingerlings and juveniles of Nile tilapia fed with probiotic (L. plantarum), differently from that observed in this study, independent of the frequency in the probiotic supply the total heterotrophic bacteria counts was not changed. The same fact were observed by YAMASHITA et al. (2017) and STANDEN et al. (2016), in which the supply of the probiotic did not interfere in the counting of total heterotrophic bacteria. In all these studies the changes or not of the amount of total heterotrophic bacteria in the intestinal tract of the fish did not interfere in the LAB probiotic effect.

Fish fed with probiotic, regardless of frequency, showed lower count of Pseudomonas spp. corroborating with the results of DEL'DUCA et al. (2013), that observed a reduction of Pseudomonas sp. and Aeromonas sp. in the intestinal microbiota of Nile tilapia fed with Bacillus sp. and Enterococcus sp. together or separately for 30 days.

The three main mechanisms of action of $\mathrm{LAB}$ are: competitive exclusion of pathogenic bacteria; production of inhibitory compounds (VERSCHUERE et al., 2000; LAZADO \& CAIPANG, 2014) and improvement of the immune response against pathogenic microorganisms

Table 2 - Means \pm standard deviation of bacterial counts (log UFC mL-) of intestinal tract of yellowtail lambari (A. bimaculatus) supplemented with probiotic (Lactobacillus spp.), offered on different frequencies.

\begin{tabular}{lcccc}
\hline Treatment & Heterotrophic Bacteria & Latic acid Bacteria & Vibrios spp. & Pseudomonas spp. \\
\hline Controle & $8.71 \pm 0.12^{\mathrm{a}}$ & $3.30 \pm 1.13^{\mathrm{a}}$ & $7.24 \pm 1.12$ & $6.74 \pm 1.04^{\mathrm{b}}$ \\
$25 \%$ & $8.79 \pm 0.10^{\mathrm{a}}$ & $7.04 \pm 1.29^{\mathrm{b}}$ & $7.42^{1}$ & $4.00 \pm 1.12^{\mathrm{a}}$ \\
$100 \%$ & $8.61 \pm 0.08^{\mathrm{a}}$ & $7.99 \pm 0.15^{\mathrm{b}}$ & $6.45^{1}$ & $4.0 \pm 0.84^{\mathrm{a}}$ \\
Significance (p) & 0.169811 & 0.0036290 & - & 0.025831 \\
\hline
\end{tabular}

${ }^{*}$ Different letters indicate significant differences $(\mathrm{P}<0.05)$ between treatments in ANOVA and in the SNK test of means separation. ${ }^{1}$ Single sample. 
(JATOBÁ et al., 2008; YAMASHITA et al., 2017) which consequently promotes general improvement of animal health (HAI, 2015).

Hybrid tilapia (O. niloticus X O. aureus) supplemented with Lactobacillus brevis were protected against the challenge with Aeromonas hydrophila (LIU et al., 2013). Nile tilapia supplemented with Bacillus subtilis and B. cereus obtained a better percentage of relative survival and also improving intestinal morphology (MELLO et al., 2013), the same was observed for yellow tail lambari fed with probiotic Lactobacillus spp. (same strain used in this study) that survival rate was $16.2 \%$ higher after experimental challenge against Aeromonas hydrophila compared to the unsupplemented group (JATOBÁ et al., 2017). Due to the changes presented in the intestinal microbiota in this study it is suggested higher resistance of the animals fed with probiotic against bacterial infections.

A higher number of total leukocytes, lymphocytes and circulating monocytes were observed in lambari fed at $100 \%$ frequency in relation to the other treatments, while glucose, hematocrit and other blood parameters did not differ among treatments (Table 3).

Changes in hematocrit and glucose levels may be associated with animal stress (GONÇALVES et al., 2011; DE PAIVA et al., 2013), the equality in these parameters showed that probiotic, regardless of frequency, did not alter fish homeostasis, suggesting that all the animals were at the same level of welfare.

The increase in leukocyte cells indicates an immunostimulation of the bloodstream cells of fish (DE PAIVA et al., 2013), demonstrating that only the constant supply $(100 \%)$ of the probiotic causes a greater recruitment of monocytes and lymphocytes in yellow tail lambari. Besides this, increasing humoral and cellular immune defenses is other way to shown probiotic benefices, as shown by GOBI et al. (2016) whom demonstrated an increase in serum immunological enzymes and antioxidant enzyme levels of Pangasius hypophthalmus fed with Bacillus licheniformis Dahb1. This same strain also demonstrated probiotic effects for tilapia enhancing immune parameters and activities of antioxidant enzymes in the serum and mucus (GOBI et al., 2016).

The change/improvement in leukogram is one of the most well-known beneficial effects of the probiotic use for fish (ALY et al., 2008; JATOBÁ et al., 2008; WANG et al., 2008; JATOBÁ et al., 2011; STANDEN et al., 2013; EISSA \& ABOU-ELGHEIT, 2014; YAMASHITA et al., 2017). The increase in circulating leukocytes corroborates IWASHITA et al. (2015) which had higher levels of white blood cells in Nile tilapia fed a diet supplemented with a combination of probiotics (Bacillus subtilis, Saccharomyces cerevisiae and Aspergillus oryzae).

Hematological alterations occurred only in fish fed with probiotic in all feeds $(100 \%)$, diverging from the results presented in the intestinal tract microbiota of the lambaris whose supply of $25 \%$ presented changes, this showed that the change in the microbiota did not guarantee an improvement/ change in immunocompetence, since the lower frequency in the supply (25\%) altered the microbiota without interfering with the hematological profile of the yellowtail lambari.

The observed values of temperature $\left(28.56 \pm 2.59^{\circ} \mathrm{C}\right)$, dissolved oxygen $(5.25 \pm 1.52 \mathrm{mg}$ $\left.\mathrm{L}^{-1}\right)$, pH $(7.43 \pm 0.11)$, total ammonia $(1,37 \pm 1.32 \mathrm{mg}$ $\left.\mathrm{L}^{-1}\right)$ and nitrite $\left(3.55 \pm 4.89 \mathrm{mg} \mathrm{L}^{-1}\right)$ did not differ among treatments and were suitable for the species (PORTO-FORESTI et al., 2005).

Table 3 - Hematological variables of yellowtail lambari (A. bimaculatus) supplemented with probiotic (Lactobacillus spp.), offered on different frequencies.

\begin{tabular}{|c|c|c|c|c|}
\hline Variables & Control & $25 \%$ & $100 \%$ & Significance \\
\hline Glucose $\left(\mathrm{mg} \mathrm{dL}^{-1}\right)$ & $138.3 \pm 46.1^{\mathrm{a}}$ & $166.9 \pm 28.4^{\mathrm{a}}$ & $132.0 \pm 80.9^{\mathrm{a}}$ & 0.388844 \\
\hline Hematocrit (\%) & $32.6 \pm 4.4^{\mathrm{a}}$ & $27.3 \pm 7.1^{\mathrm{a}}$ & $34.6 \pm 19.2^{\mathrm{a}}$ & 0.077682 \\
\hline Erythrocytes $\left(\times 10^{6} \mu \mathrm{L}^{-1}\right)$ & $2.0 \pm 13.2^{\mathrm{a}}$ & $1.6 \pm 38.2^{\mathrm{a}}$ & $2.3 \pm 61.0^{\mathrm{a}}$ & 0.195220 \\
\hline thrombocyte $\left(\times 10^{3} \mu \mathrm{L}^{-1}\right)$ & $6.0 \pm 2.1^{\mathrm{a}}$ & $4.1 \pm 1.3^{\mathrm{a}}$ & $5.1 \pm 2.6^{\mathrm{a}}$ & 0.143155 \\
\hline Leucocytes $\left(\times 10^{3} \mu \mathrm{L}^{-1}\right)$ & $27.1 \pm 5.9^{\mathrm{a}}$ & $29.0 \pm 10.0^{\mathrm{a}}$ & $47.7 \pm 6.7^{b}$ & 0.031517 \\
\hline Lymphocytes $\left(\times 10^{3} \mu \mathrm{L}^{-1}\right)$ & $23.0 \pm 6.3^{\mathrm{a}}$ & $23.0 \pm 7.3^{\mathrm{a}}$ & $36.0 \pm 2.6^{\mathrm{b}}$ & 0.047917 \\
\hline Monocytes $\left(\mathrm{x} 10^{3} \mu \mathrm{L}^{-1}\right)$ & $4.7 \pm 1.0^{\mathrm{a}}$ & $5.4 \pm 3.3^{\mathrm{a}}$ & $12.0 \pm 4.2^{b}$ & 0.036624 \\
\hline
\end{tabular}

"Different letters indicate significant differences $(\mathrm{p}<0.05)$ between treatments in ANOVA and in the SNK test of means separation. 
Fish fed with probiotic in $100 \%$ of feeds shown an increase of $17.3 \%$ in final weight and $21.2 \%$ in weekly growth than fish fed control diet (not supplemented), while those fed with $25 \%$ of diets supplemented with probiotic did not differ between treatments. The survival, feed efficiency and yield did not show significant differences among treatments (Table 4). The higher frequency in the probiotic supply suggested higher concentrations of microorganisms, so this result corroborates with GOBI et al. (2018) that observed higher final weight in tilapia (O. mossambicus) fed with the highest concentration of probiotic (Bacillus licheniformis Dahb1).

One of the benefits of probiotic use is the better absorption of nutrients by animals (FERREIRA et al., 2015). This effect was observed in Nile tilapia autochthone probiotic, after been reared for 35 days, shown higher final weight and weekly growth (JATOBÁ \& MOURIÑO, 2015), as well as Nile tilapia fed commercial probiotic mix in the diet administered for 6 weeks (STANDEN et al., 2015).

Effect of probiotics on specific growth rate and weekly gain are divergent, it is possible to find authors who prove their efficacy, improving up to $15 \%$ of the feed efficiency of animals fed with autochthonous probiotic (JATOBÁ \& MOURIÑO, 2015; YAMASHITA et al., 2017), as well as others did not observed improvement in these zootechnical variables for Nile tilapia (O. niloticus) fed with probiotic (Saccharomyces cervisiae), prebiotic (mananoligosaccharide) and symbiotic ( $S$. cervisiae + nanaoligosaccharide) (SCHWARZ et al., 2016), this divergence may be related to the specificity between host-host, justifying the best results of the autochthonous bacteria. Probiotic bacteria capable of acting in several (more than one) species are especially attractive to aquaculture, because they can be used in integrated and polyculture systems, such as Bacillus licheniformis Dahb1 which demonstrated beneficial effects for P. hypophthalmus and O. mossambicus (GOBI et al., 2016; 2018); and L. plantarum for O. niloticus and Litopenaeus vannamei (JATOBÁ et al., 2011).

The apparent feed efficiency (AFE)/ feed conversion (FC) are parameters that alleviate the ratio of feed consumption with produced biomass; however, whether the probiotic used does not improve the absorption or attractiveness of the diet, as well as does not promote fast growth, the relation consumption/weight gain will not be affected (TELLI et al., 2014; STANDEN et al., 2015). However, several authors observed greater weight gain and weekly growth in conjunction with better AFE and/or FC (JATOBÁ et al., 2011; CORNÉLIO et al., 2013; JATOBÁ \& MOURIÑO 2015; SCHWARZ et al., 2016; YAMASHITA et al., 2017), despite Lactobacillus spp. (same strain) to increase the villus length and number of villi in the intestinal mucosa of lambari of the yellow tail (JATOBÁ et al., 2017), in this research no better absorption of nutrients was observed.

The changes of the intestinal tract microbiota associated with the increase in the number of total leukocytes, monocytes and lymphocytes are indicative of an improvement in the animal immunity, justifying the higher survival rate of fish fed probiotic diets in relation to fish that did not eat it, or ate in inadequate quantity and/or frequency, when challenged experimentally or not (JATOBÁ et al., 2011; MELLO et al., 2013; TELLI et al., 2014).

Experiment performed with Nile tilapia fed with $L$. plantarum reported that the supply of probiotic in $50 \%$ of feeds guarantee better growth performance,

Table 4 - Growth performance of yellowtail lambari (A. bimaculatus) supplemented with probiotic (Lactobacillus spp.), offered on different frequencies.

\begin{tabular}{|c|c|c|c|c|}
\hline \multirow[t]{2}{*}{ Zootechnical variables } & \multicolumn{3}{|c|}{ 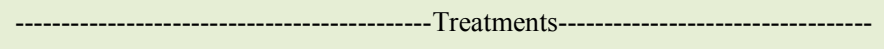 } & \multirow[t]{2}{*}{ Significance $(\mathrm{p})$} \\
\hline & Control & $25 \%$ & $100 \%$ & \\
\hline Final weight average (g) & $9.03 \pm 0.39^{b}$ & $10,00 \pm 0,24^{\mathrm{ab}}$ & $10,60 \pm 0,89^{\mathrm{a}}$ & 0,041259 \\
\hline Weekly growth (g.week ${ }^{-1}$ ) & $0,66 \pm 0,03^{b}$ & $0,75 \pm 0,02^{\mathrm{ab}}$ & $0,80 \pm 0,08^{\mathrm{a}}$ & 0,039624 \\
\hline Survival (\%) & $85,33 \pm 12,42^{\mathrm{a}}$ & $81,33 \pm 14,22^{\mathrm{a}}$ & $88,00 \pm 9,17^{\mathrm{a}}$ & 0,801262 \\
\hline Apparent feed efficiency & $0,53 \pm 0,07^{\mathrm{a}}$ & $0,48 \pm 0,11^{\mathrm{a}}$ & $0,59 \pm 0,03^{\mathrm{a}}$ & 0,270363 \\
\hline Yield $\left(\mathrm{kg} \cdot \mathrm{m}^{-3}\right)$ & $0,92 \pm 0,18^{\mathrm{a}}$ & $0,97 \pm 0,16^{\mathrm{a}}$ & $1,11 \pm 0,02^{\mathrm{a}}$ & 0,287978 \\
\hline
\end{tabular}

${ }^{*}$ Different letters indicate significant differences $(\mathrm{p}<0.05)$ between treatments in ANOVA and in the SNK test of means separation. 
(JATOBÁ et al., 2018), unlike that observed in this study, for lambari yellow tail, Lactobacillus spp. used should be offered in all feedings to guarantee the probiotic effect. This divergence may be related to animal physiology, since the digestive tract of Nile tilapia is longer than lambari yellow tail, allowing longer residence time of the probiotic microorganisms in the digestive tract.

\section{CONCLUSION}

Probiotic (Lactobacillus spp.) offered in $25 \%$ of feeds (or more) alters the yellowtail lambari microbiota (A. bimaculatus); however, must be offer in $100 \%$ of feeds to improve the hematology profile and productive performance. The frequency of probiotic (Lactobacillus spp.) supply influences the microbiota, hematology and growth performance of yellowtail lambari (A. bimaculatus).

\section{ACKNOWLEDGEMENTS}

The authors of this study acknowledge (CNPq) Conselho Nacional de Desenvolvimento Cientıfico e Tecnologico, process 460362/2014-3) and (FAPESC) Fundação de Amparo a Pesquisa do Estado de Santa Catarina, process 2015TR1703 for funding; GUABI for financing the diets used; and Luiz Sergio Moreira for technical support.

\section{DECLARATION OF CONFLICTING OF INTERESTS}

The authors declared no potential conflicts of interest with respect to the research, authorship, and/or publication of this article.

\section{AUTHORS' CONTRIBUTIONS}

Adolfo Jatobá and Klayton Natan Moraes conceived and designed experiments. All authors performed the experiments, Emanuel Fernandes Rodrigues, Leandro Marcolino Vieira, Marina Oliveira Pereira carried out the lab analyses. Adolfo Jatobá supervised and coordinated the animal experiments, provided clinical data and performed statistical analyses of experimental data. Adolfo Jatobá e Marina Oliveira Pereira prepared the draft of the manuscript. All authors critically revised the manuscript and approved of the final version.

\section{REFERÊNCIAS}

ALY, S.M. et al. Studies on Bacillus subtilis and Lactobacillus acidophilus, as potential probiotics, on the immune response and resistance of Tilapia nilotica (Oreochromis niloticus) to challenge infections. Fish \& Shellfish Immunology, v.25, n.1, p.128-136, 2008. Available from: <http://www.sciencedirect.com/science/ article/pii/S1050464808000831>. Accessed: Jan. 18, 2018. doi: 10.1016/j.fsi.2008.03.013.
CORNÉLIO, F.H.G. et al. Growth, digestibility and resistance to pathogen infection in Nile tilapia fed with probiotics. Pesquisa Agropecuária Brasileira, v.48, n.8, p.863-870, 2013. Available from: $<$ https://seer.sct.embrapa.br/index.php/pab/article/view/11483/12285>. Accessed: Jan. 18, 2018. doi: 10.1590/S0100-204X2013000800008.

DE PAIVA, M.J.T.R. et al. Métodos para análise hematológica em peixes. Editora da Universidade Estadual de Maringá-EDUEM, 2013.

DEL'DUCA, A. et al. Evaluation of the presence and efficiency of potential probiotic bacteria in the gut of tilapia (Oreochromis niloticus) using the fluorescent in situ hybridization technique. Aquaculture, v.388, p.115-121, 2013. Available from: <http:// www.sciencedirect.com/science/article/pii/S0044848613000343>. Accessed: Jan. 18, 2018. doi: 10.1016/j.aquaculture.2013.01.019.

EISSA, N.; ABOU-ELGHEIT, E. Dietary supplementation impacts of potential non-pathogenic isolates on growth performance, hematological parameters and disease resistance in Nile Tilapia (Oreochromis Niloticus). Journal of Veterinary Advances, v.4, n.10, p.712-719, 2014. Available from: <https://s3.amazonaws. com/academia.edu.documents/35339762/741413257869.pdf? AWSAccessKeyId=AKIAIWOWYYGZ2Y 53UL3A\&Expire $\mathrm{s}=1516368051 \&$ Signature $=$ QAQw AypMw74zQMPbYKkrN qPNG4w\%3D\&response-content-disposition=inline $\% 3 \mathrm{~B} \% 20$ filename\%3DDietary_Supplementation_Impacts_of_Poten.pdf $>$. Accessed: Jan. 18, 2018. doi: 10.5455/jva.20141025045451.

FERREIRA, A.H.C. et al. Probiótico na alimentação de póslarvas de tilápias-do-nilo submetidas a desafio sanitário. Revista Brasileira de Saúde e Produção Animal, v.16, n.2, p.430-439, 2015. Available from: $<$ http://revistas.bvs-vet.org.br/rbspa/article/ view/27033>. Accessed: Jan. 18, 2018.

GOBI, Narayanan et al. Dietary supplementation of probiotic Bacillus licheniformis Dahb1 improves growth performance, mucus and serum immune parameters, antioxidant enzyme activity as well as resistance against Aeromonas hydrophila in tilapia Oreochromis mossambicus. Fish \& Shellfish Immunology, 2018. Available from: <https://www.sciencedirect.com/science/ article/pii/S105046481730815X>. Accessed: May 11, 2018. doi: 10.1016/j.fsi.2017.12.066.

GOBI, Narayanan et al. GFP tagged Vibrio parahaemolyticus Dahv2 infection and the protective effects of the probiotic Bacillus licheniformis Dahb1 on the growth, immune and antioxidant responses in Pangasius hypophthalmus. Fish \& Shellfish Immunology, v. 52, p. 230-238, 2016. Available from: <https:// www.sciencedirect.com/science/article/pii/S1050464816300857>. Accessed: May 11, 2018. doi: 10.1016/j.fsi.2016.03.006.

GONÇALVES, A.T. et al. Effects of a probiotic bacterial Lactobacillus rhamnosus dietary supplement on the crowding stress response of juvenile Nile tilapia Oreochromis niloticus. Fisheries Science, v.77, n.4, p.633-642, 2011. Available from: <https://link.springer.com/article/10.1007/s12562-011-0367-2>. Accessed: Jan. 18, 2018. doi: 10.1007/s12562-011-0367-2.

HAI, N.V. Research findings from the use of probiotics in tilapia aquaculture: a review. Fish \& Shellfish Immunology, v.45, n.2, p.592-597, 2015. Available from: <http://www.sciencedirect.com/ science/article/pii/S1050464815002454>. Accessed: Jan. 18, 2018. doi: 10.1016/j.fsi.2015.05.026.

IWASHITA, M.K.P. et al. Dietary supplementation with Bacillus subtilis, Saccharomyces cerevisiae and Aspergillus oryzae enhance 
immunity and disease resistance against Aeromonas hydrophila and Streptococcus iniae infection in juvenile tilapia Oreochromis niloticus. Fish \& Shellfish Immunology, v.43, n.1, p.60-66, 2015. Available from: $<$ http://www.sciencedirect.com/science/article/pii/ S1050464814004793>. Accessed: Jan. 18, 2018. doi: 10.1016/j. fsi.2014.12.008.

JATOBÁ, A. et al. Diet supplemented with probiotic for Nile tilapia in polyculture system with marine shrimp. Fish Physiology and Biochemistry, v.37, n.4, p.725-732, 2011. Available from: $<$ https://link.springer.com/article/10.1007/s10695-011-9472-5>. Accessed: Jan. 19, 2018. doi: 10.1007/s10695-011-9472-5.

JATOBÁ, A. et al. Action time and feed frequency of Lactobacillus plantarum for Nile tilapia. Arquivo Brasileiro de Medicina Veterinária e Zootecnia, v. 70, n. 1, p. 327-332, 2018. Available from: <http://www.scielo.br/scielo.php?pid=S010209352018000100327\&script=sci_arttext $>$. Accessed: May 11, 2018. doi: 10.1590/1678-4162-9870.

JATOBÁ, A. et al. Lactic-acid bacteria isolated from the intestinal tract of Nile tilapia utilized as probiotic. Pesquisa Agropecuária Brasileira, v.43, n.9, p.1201-1207, 2008. Available from: <http://www.scielo.br/scielo.php?pid=S0100204X2008000900015\&script $=$ sci_arttext $>$. Accessed: Jan. 19, 2018. doi: 10.1590/S0100-204X2008000900015.

JATOBÁ, A. et al. Selection of autochtone probiotic for Astyanax bimaculatus. Arquivo Brasileiro de Medicina Veterinária e Zootecnia, v.69, n.6, p.1645-1652, 2017. Available from: $<$ http://www. scielo.br/scielo.php?pid=S0102-09352017000601645\&script $=$ sci arttext $>$. Accessed: Jan. 19, 2018. doi: 10.1590/1678-4162-9158.

JATOBÁ, A.; MOURIÑO, J.L.P. Efeito do Lactobacillus plantarum no trato intestinal de alevinos de Oreochromis niloticus. Ciência Animal Brasileira, v.16, n.1, p.45-53, 2015. Available from: <http://189.126.110.61/cab/article/view/25259>. Accessed: Jan. 19, 2018. doi: 10.1590/1089-68916i127789.

LAZADO, C.C.; CAIPANG, C.M.A. Mucosal immunity and probiotics in fish. Fish \& Shellfish Immunology, v.39, n.1, p.7889, 2014. Available from: <http://www.sciencedirect.com/science/ article/pii/S1050464814001314>. Accessed: Jan. 19, 2018. doi: 10.1016/j.fsi.2014.04.015.

LIU, W. et al. Comparison of adhesive gut bacteria composition, immunity, and disease resistance in juvenile hybrid tilapia fed two different Lactobacillus strains. Fish \& Shellfish Immunology, v.35, n.1, p.54-62, 2013. Available from: <http:// www.sciencedirect.com/science/article/pii/S1050464813004993>. Accessed: Jan. 19, 2018. doi: 10.1016/j.fsi.2013.04.010.

MELLO,H. etal.Efeitos benéficos deprobióticos no intestino dejuvenis de Tilápia-do-Nilo. Pesquisa Veterinária Brasileira, p.724-730, 2013. Available from: $<\mathrm{https} / /$ repositorio.unesp.br/bitstream/handle $/ 11449 / 76301 / 2$ s2 .084881530200 .pdf? sequence $=1$ \&isAllowed $=y>$. Accessed: Jan. 19, 2018. doi: 10.1590/S0100-736X2013000600006.

PORTO-FORESTI, F. et al. Biologia e criação do lambari-dorabo-amarelo (Astyanax altiparanae). Espécies nativas para piscicultura no Brasil, v.2, p.101-116, 2005.

Rosenfeld, G. Corante pancrônico para hematologia e citologia clínica. Nova combinação dos componentes do May-Grünwald e do Giemsa num só corante de emprego rápido. Memórias do Instituto Butantan, v.20, p.329-334, 1947.
SCHWARZ, K.K. et al. Probiótico, prebiótico e simbiótico na nutrição de alevinos de tilápia do nilo Oreochromis niloticus. Archives of Veterinary Science, v.21, n.2, 2016. Available from: $<$ http://revistas.ufpr.br/veterinary/article/view/44179/29568>. Accessed: Jan. 23, 2018. doi: 10.5380/avs.v21i2.44179.

STANDEN, B.T. et al. Dietary administration of a commercial mixedspecies probiotic improves growth performance and modulates the intestinal immunity of tilapia, Oreochromis niloticus. Fish \& Shellfish Immunology, v.49, p.427-435, 2016. Available from: <http:// www.sciencedirect.com/science/article/pii/S1050464815302564>. Accessed: Jan. 23, 2018. doi: 10.1016/j.fsi.2015.11.037.

STANDEN, B.T. et al. Modulation of the intestinal microbiota and morphology of tilapia, Oreochromis niloticus, following the application of a multi-species probiotic. Applied Microbiology and Biotechnology, v.99, n.20, p.8403-8417, 2015. Available from: $<$ https://link.springer.com/article/10.1007/s00253-015-6702-2>. Accessed: Jan. 24, 2018. doi: 10.1007/s00253-015-6702-2.

STANDEN, B.T. et al. Probiotic Pediococcus acidilactici modulates both localised intestinal-and peripheral-immunity in tilapia (Oreochromis niloticus). Fish \& Shellfish Immunology, v.35, n.4, p.1097-1104, 2013. Available from: <http://www. sciencedirect.com/science/article/pii/S1050464813006566>. Accessed: Jan. 23, 2018. doi: 10.1016/j.fsi.2013.07.018.

TELLI, G.S. et al. Dietary administration of Bacillus subtilis on hematology and non-specific immunity of Nile tilapia Oreochromis niloticus raised at different stocking densities. Fish \& Shellfish Immunology, v.39, n.2, p.305-311, 2014. Available from: <http:// www.sciencedirect.com/science/article/pii/S1050464814001740>. Accessed: Jan. 23, 2018. doi: 10.1016/j.fsi.2014.05.025.

VASEEHARAN, B. A. R. P.; RAMASAMY, P. Control of pathogenic Vibrio spp. by Bacillus subtilis BT23, a possible probiotic treatment for black tiger shrimp Penaeus monodon. Letters in Applied Microbiology, v. 36, n. 2, p. 83-87, 2003. Available from: $<$ https://onlinelibrary.wiley.com/doi/full/10.1046/ j.1472-765X.2003.01255.x>. Accessed: May 11, 2018. doi: 10.1046/j.1472-765X.2003.01255.x.

VASEEHARAN, B. et al. Effect of probiotics, antibiotic sensitivity, pathogenicity, and plasmid profiles of Listonella anguillarumlike bacteria isolated from Penaeus monodon culture systems. Aquaculture, v. 241, n. 1-4, p. 77-91, 2004. Available from: <https:// www.sciencedirect.com/science/article/pii/S0044848604005289>. Accessed: May 11, 2018. doi: 10.1046/j.1472-765X.2003.01255.x.

VERSCHUERE, L. et al. Probiotic bacteria as biological control agents in aquaculture. Microbiology and Molecular Biology Reviews, v.64, n.4, p.655-671, 2000. Available from: <http:// mmbr.asm.org/content/64/4/655.full.pdf + html $>$. Accessed: Jan. 23, 2018. doi: 10.1128/MMBR.64.4.655-671.2000.

WANG, Y.B. et al. Effect of probiotics, Enteroccus faecium, on tilapia (Oreochromis niloticus) growth performance and immune response. Aquaculture, v.277, n.3, p.203-207, 2008. Available from: <http:// www.sciencedirect.com/science/article/pii/S0044848608001488>. Accessed: Jan. 23, 2018. doi: 10.1016/j.aquaculture.2008.03.007.

YAMASHITA, M.M. et al. Probiotic dietary supplementation in Nile tilapia as prophylaxis against streptococcosis. Aquaculture Nutrition, v. 23, n. 6, p. 1235-1243, 2017. Available from: <http:// onlinelibrary.wiley.com/doi/10.1111/anu.12498/full >. Accessed: Jan. 23, 2018. doi: 10.1111/anu.12498. 